The text also briefly describes the species' diagnostic identification features. Here the authors have been very innovative: they have emphasized the most prominent features by underlining them and pointing to them in the species' illustration on the facing page; a short comparison with potentially confusing species is also provided. Additional text provides an aid to a better understanding of the behaviors and habitats occupied by the species. Other natural history information provided includes the species' foods, nest characteristics, clutch size, egg size and laying period, and the number of days in the incubation and nestling periods; also mentioned is how many years it takes an individual to reach sexual maturity. Lastly, the authors discuss the species' conservation status and population trend in Georgia. A color-coded map shows the species' year-round distribution.

The facing (illustration) page depicts the species. I found it very instructive that the authors chose to show each of the sexes in separate columns and, where relevant, they illustrated different morphs at different ages. Lines point to the most diagnostic features to look for during field observation. I especially enjoyed the sketches that show habitats in which the species should be found, or engaged in some unique behavior, and the fact that-interspersed between the species accountsthere are two pages of field drawings of species addressed in the previous pages. These drawings illustrate habitats, behaviors, prey, inter- and intra-specific interactions, and nest structures and locations.

I greatly appreciate this compact field guide. It will be a good companion for raptor watchers who will find that it is relevant not only to Georgia but also to most of the neighboring countries (i.e., all of the Caucasus region). The only flaws I found in the book were in the illustrations. A few of the drawings contain errors, including some that do not correctly depict the raptor's exact "jizz" and posture; examples of this problem may be found on page 83 in the drawings of Honey Buzzards. I also found the plates too dark. I have handled hundreds of raptors every year for more than a decade and know these birds up close - the colors of most are not as dark as they are in the illustrations. This criticism, however, should not put off raptorphiles or birdwatchers that need a good raptor identification guide for that part of the world. Furthermore, proceeds from the sales of this book are donated to the Georgian Centre for the Conservation of Wildlife and to conservation efforts within the region. On the whole, this is a worthwhile undertaking by local ornithologists whose worthy endeavors within the region deserve recognition.-REUVEN YOSEF, International Birding and Research Center, Eilat, Israel; e-mail: ryosef@eilatcity.co.il

\section{BIRDS OF MEXICO AND CENTRAL} AMERICA. By Ber Van Perlo. Princeton University Press, Princeton, New Jersey. 2006: 336 pp., 98 color plates. ISBN: 0691120706. $\$ 29.95$ (paper).-The format of this newest guide in the Princeton Illustrated Checklist series is best described as an abbreviated field guide format. The guide covers Mexico and all of Central America to Panama-a vast area containing a huge number of species $(1,574)$ to illustrate in a single guide. The 98 color plates have thumbnail illustrations of the birds and a brief text (on the facing, or a nearby, page). Maps showing geographic distributions follow the color plates. Other than an index, table of contents, and brief introductory pages, that is the total extent of this guide. This book should not be viewed as a replacement for books like Howell and Webb's excellent, comprehensive guide (Howell, S. N. G. and S. Webb. 1995. A Guide to the Birds of Mexico and Northern Central America. Oxford University Press, New York), which provides a much more complete account for each species, including in-depth coverage of identification, distribution, taxonomy, vocalizations, and more. This is a compact and useful guide to tote in the field, however it only complements rather than replaces handbooks like Howell and Webb's guide.

The plates are generally well done and illustrate all species found in the area, including hypothetical or rare species, whereas the Howell and Webb guide omits illustrations of many North American migratory passerines and provides only black and white drawings for some waterbirds. The plates in Princeton's Illustrated Checklist, however, do not depict all the plumages essential for identification; 
for example, immature plumages of Great Blue Heron (Ardea herodias), Cooper's Hawk (Accipiter cooperii), Cedar Waxwing (Bombycilla cedrorum), Loggerhead (Lanius ludovicianus) and Northern (L. excubitor) shrikes, Scissor-tailed Flycatcher (Tyrannus forficatus), Prairie Warbler (Dendroica discolor), and Chestnut-sided Warbler (Dendroica pensylvanica) are not included. The plates and text will not help with more difficult identifications; even adult Glossy (Plegadis falcinellus) and White-faced (P. chihi) ibis, or Rusty (Euphagus carolinus) and Brewer's (E. cyanocephalus) blackbirds will be unidentifiable if only this guide is used. The immature Whitetailed Hawk (Buteo albicaudatus) is labeled in the text as not identifiable, and the illustration does not show one representative age, making correct identification impossible.

Unlike many Latin American guides that include North American migrants, the plates of these species are fairly well done. I could quibble with illustrations like that of the Pine Siskin (Carduelis pinus), but in general the illustrations are accurate. Indications of changes in scale within a given plate were not provided; for example, plate 77 depicts Green Shrike-Vireo (Vireolanius pulchellus) and gnatcatchers as being the same size. On another plate, the Red-winged Blackbird (Agelaius phoeniceus) male and female are the same size and are illustrated as larger than the Yellow-headed Blackbird (Xanthocephalus xanthocephalus). Among the illustrations of neotropical species, some could have been better portrayed or benefitted from another view. For example, the unique tail pattern of the Olivaceous Piculet (Picumnus olivaceus) is not illustrated or described, and the tuft on the Tufted Flycatcher (Mitrephanes phaeocercus) is very weak and the illustration does not look much like the species. The text accompanying the illustrations is concise and provides codes for range, status (endemic, hypothetical, rare, etc.), and seasonality. There are several problems, however, including a reversed caption or plate number (Baltimore [ICterus galbula] and Orchard [I. spurious] orioles), and inappropriate abbreviations of common names (e.g., "Grosbeak" for Blue Grosbeak, Passerina caerulea). Most common names and taxonomy follow the American Ornithologists' Union, but there are exceptions, including the use of the common name Gray Plover for Black-bellied Plover (Pluvials squatarola) and the split of Stephen's (Mexican) Whip-poor-will (Caprimulgus arizonae) from Whip-poor-will (Caprimulgus vocifer$u s)$.

The text for each plate often extends to the next page, adjacent to the following plate, the text for which then also runs over to the next page, and so on until half the text on any one page may pertain to the current plate and half to the preceding plate. Eventually it evens out (or additional textual pages are included), but this makes the guide more difficult to use (albeit slightly). The maps are understandably small, as there are 27 maps per page, each including the species' name, plate number, and the species' number on the plate to aid cross-referencing between the maps and plates. A neat innovation is that the maps show the species' detectabilities (common to frequent, frequent to uncommon, uncommon to rare; or a percent likelihood of detectability) and status (resident, transient, present in northern winter or northern summer). This allows the maps to convey more information than just presence/absence for a given location, making them extremely useful. Locations of rarities or isolated populations are identified with cross hairs or stars.

I have quibbled over some issues in this guide, but I am very pleased to have it available and I will give it the greatest complement I can give to a field guide; I will use it. I will carry this guide in the field and leave both $A$ Guide to the Birds of Mexico and Northern Central America and The Sibley Guide to Birds (Sibley, D. A. 2000. The Sibley Guide to Birds. Alfred A. Knopf, New York.) in the car. This guide will be especially useful for those unfamiliar with the North American migrants and who want illustrations of the migrant and resident birds in one small volume. If this guide were to be translated into Spanish, it would become the standard guide for use in Mexico and Latin America; thus, publication of a Spanish version should be a high priority to benefit conservation and education in the region.-MARY GUSTAFSON, Rio Grande Joint Venture, Texas Parks and Wildlife Department, Mission, Texas; e-mail: mary.gustafson@tpwd.state.tx.us 


\section{$2 \mathrm{BHL}$ Biodiversity Heritage Library}

Gustafson, Mary. 2006. "Ornithological Literature." The Wilson journal of ornithology 118(4), 583-584.

https://doi.org/10.1676/1559-4491(2006)118[583:ol]2.0.co:2.

View This Item Online: https://www.biodiversitylibrary.org/item/214888

DOI: https://doi.org/10.1676/1559-4491(2006)118[583:ol]2.0.c0;2

Permalink: https://www.biodiversitylibrary.org/partpdf/240836

\section{Holding Institution}

Harvard University, Museum of Comparative Zoology, Ernst Mayr Library

\section{Sponsored by}

IMLS LG-70-15-0138-15

\section{Copyright \& Reuse}

Copyright Status: In copyright. Digitized with the permission of the rights holder.

Rights Holder: Wilson Ornithological Society

License: http://creativecommons.org/licenses/by-nc-sa/4.0/

Rights: https://biodiversitylibrary.org/permissions

This document was created from content at the Biodiversity Heritage Library, the world's largest open access digital library for biodiversity literature and archives. Visit BHL at https://www.biodiversitylibrary.org. 